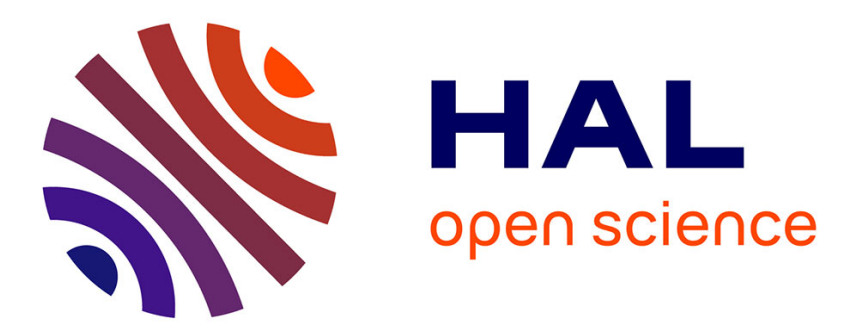

\title{
Post-intensive Care Syndrome in Relatives of Critically Ill Patients
}

Audrey de Jong, Nancy Kentish, Virginie Souppart, Samir Jaber, Elie Azoulay

\section{To cite this version:}

Audrey de Jong, Nancy Kentish, Virginie Souppart, Samir Jaber, Elie Azoulay. Post-intensive Care Syndrome in Relatives of Critically Ill Patients. Post-Intensive Care Syndrome, 2020, pp.247-259, 2020. hal-02280959

\section{HAL Id: hal-02280959 https://hal.science/hal-02280959}

Submitted on 24 Nov 2021

HAL is a multi-disciplinary open access archive for the deposit and dissemination of scientific research documents, whether they are published or not. The documents may come from teaching and research institutions in France or abroad, or from public or private research centers.
L'archive ouverte pluridisciplinaire HAL, est destinée au dépôt et à la diffusion de documents scientifiques de niveau recherche, publiés ou non, émanant des établissements d'enseignement et de recherche français ou étrangers, des laboratoires publics ou privés. 


\title{
Post-intensive Care Syndrome in Relatives of Critically III Patients
}

\author{
Audrey de Jong, Nancy Kentish, Virginie Souppart, Samir Jaber, and Elie \\ Azoulay
}

17.1 Introduction

$-248$

17.2 Anxiety and Depression

$-249$

17.3 Post-traumatic Stress Disorder

$-252$

17.4 Cognitive Dysfunction

$-256$

17.5 Time Points for Family Management

$-256$

References

$-257$

\section{Learning Objectives}

After reading this chapter, the learner will be able to understand:

That anxiety, depression, and post-traumatic stress disorder (PTSD) symptoms are frequent in relatives of ICU patients

The importance to decrease family burden and how to implement several strategies to lessening them

That up to $40 \%$ of family members suffer from at least one psychiatric illness 1 year after the patient's ICU stay How a family information leaflet, an appropriate waiting room, and the use of an ICU diary and of an ICU communication facilitator should be implemented by the ICU team

\subsection{Introduction}

In recent years, while technical improvements have been translated into increase of survival rates in critically ill patients, physicians and nurses in intensive care units (ICUs) have developed a strong interest in family members, creating the concept of family-centred care [1-4]. Awareness of the distress experienced by families of ICU patients is increasing, and family members are no longer considered as simple visitors to the ICU. On the contrary, family members receive dedicated communication aiming to reduce their psychological burden during and after the ICU stay. Studies have been conducted both to assess the health impact of the ICU experience on family members and to measure the effects of preventive interventions. Anxiety, depression, post-traumatic stress disorders (PTSD), and cognitive dysfunction are the main psychological impairments observed in family members. These conditions are known as post-intensive care syndrome - family, or PICS-F [5]. Strategies aiming to decrease family burden in ICUs [6] will be detailed in this chapter and are summarized in . Figs. 17.1 and 17.2. 


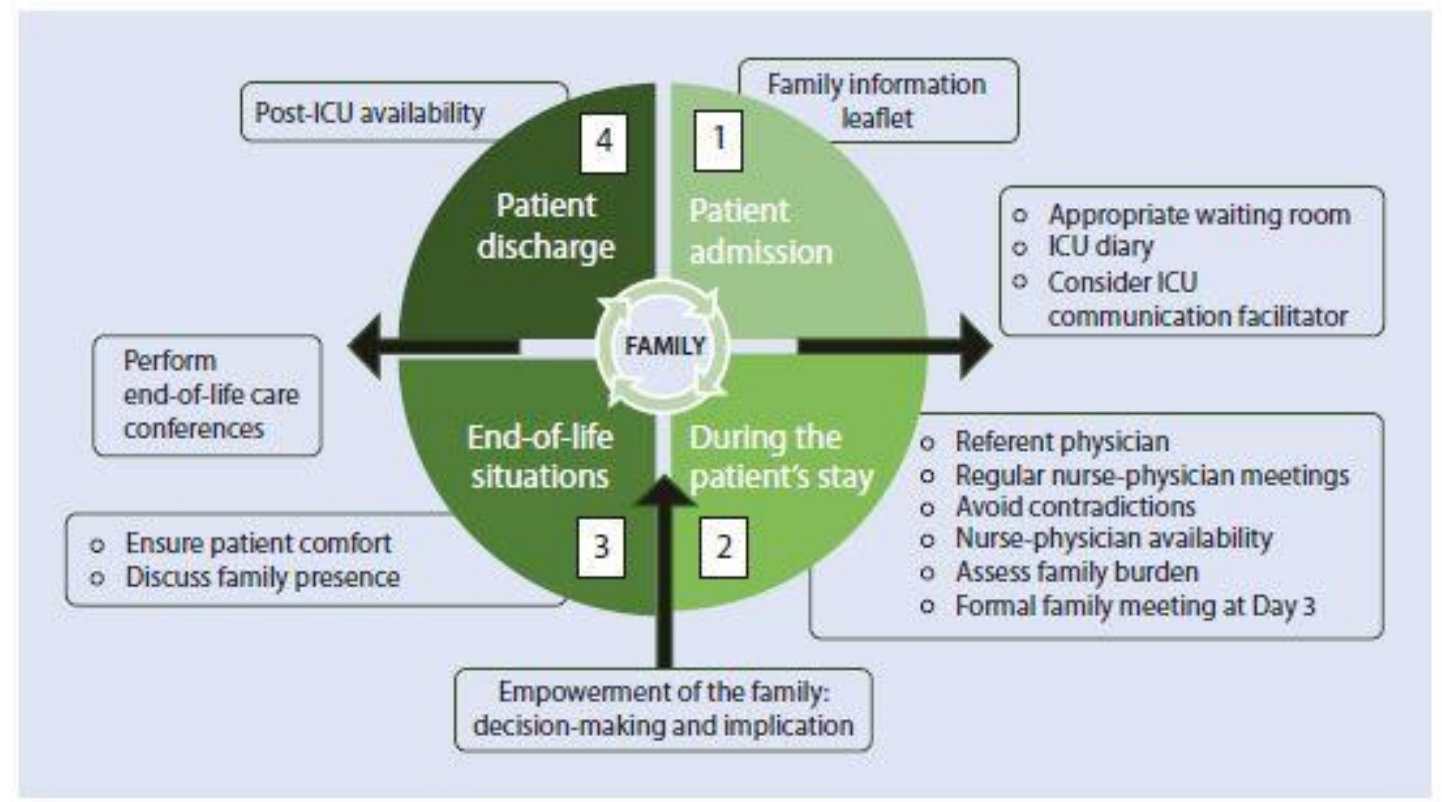

Fig. 17.1 Tools and strategies available to decrease family burden in intensive care units. ICU intensive care unit

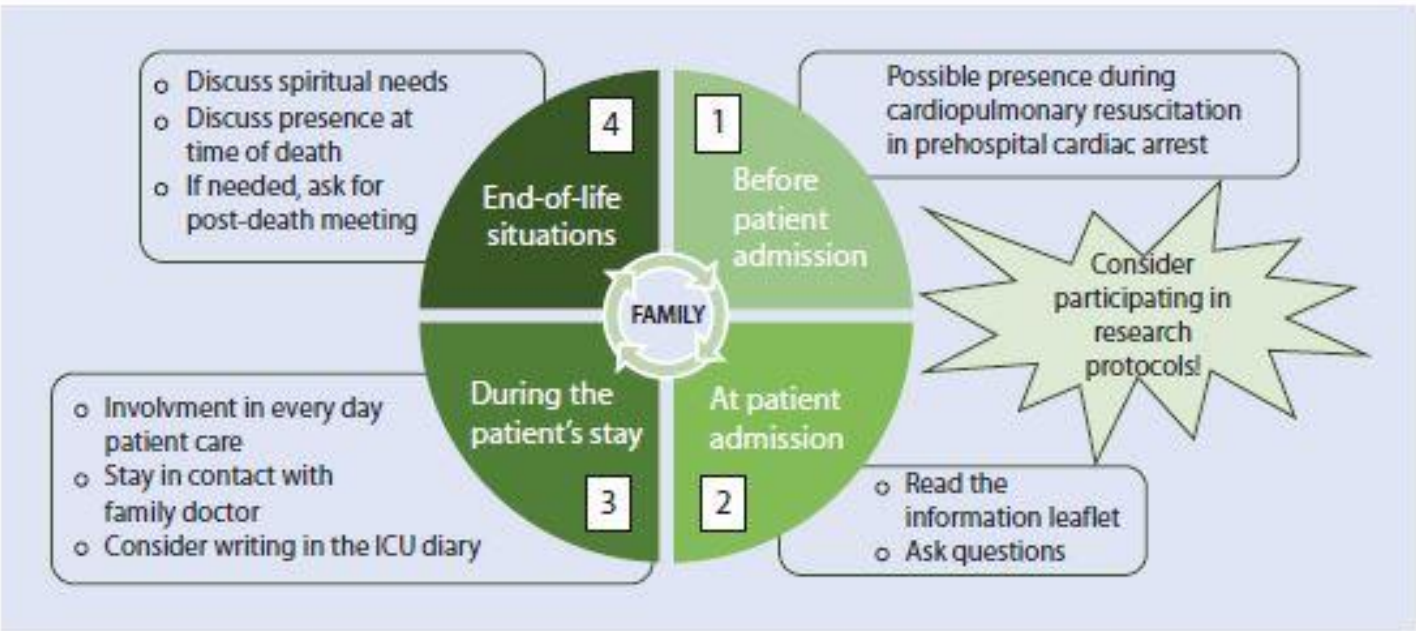

.. Fig. 17.2 Empowering family members to decrease their burden in intensive care units. ICU intensive care unit

\subsection{Anxiety and Depression}

Anxiety and depression are symptoms that can considerably alter a person's quality of life and can hinder their understanding of a situation. Symptoms of anxiety and depression can be detected using the Hospital Anxiety and Depression Scale (HADS) developed by Zigmond and Snaith in 1983 [7] which is a 14-item self-screening questionnaire. Seven items evaluate depression and seven items assess anxiety. Each item is scored on a $0-3$ scale, so that scores can range from 0 to 21 for anxiety and 0 to 21 for depression. The HADS takes only $2-$ 5 min to complete. These symptoms are common in relatives of ICU patients, as shown in many studies. In a French prospective multicentre study [8], symptoms of anxiety or depression were present in $73 \%$ of family members and $84 \%$ of spouses. Risk factors for anxiety and depression symptoms were identified, including non-modifiable factors such as 
age and female gender. Modifiable factors were the absence of regular physician and nurse meetings, the absence of a room used only for meetings with family members, the absence of a waiting room, and perceived contradictions in the information provided by caregivers. When defining the organization and policies of their ICU, caregivers should bear in mind the need to decrease the risk of anxiety and depression in family members. Based on these data, these steps should include holding regular nurse-physician meetings to discuss patient and family needs, having a dedicated information room, having a waiting room, and ensuring that there are no contradictions in the information given to families. In a complementary study [9], it was found that in 54\% of cases, the representative failed to understand the diagnosis, prognosis, or treatment of the patient. Physician-related factors of poor comprehension were a first meeting with representative $<10 \mathrm{~min}$ and failure to give the relative an information brochure.

In order to improve family members' experience, a preventive strategy, aimed to increase family understanding and satisfaction and decrease symptoms of anxiety and depression, was assessed, using a family information leaflet (FIL), in addition to standard information [10]. The leaflet aims to give simple, practical information to people whose relatives are admitted to the ICU. It includes general information about the ICU and hospital, with phone numbers, visiting hours, a diagram of a typical ICU room, and a glossary. A prospective randomized controlled trial [10] was performed in 34 French ICUs, assessing comprehension of diagnosis, prognosis, and treatment, satisfaction with information, and anxiety and depression according to the providing or not of the FIL. Interestingly, anxiety and depression rates were not significantly different between the two randomized groups, whereas comprehension and satisfaction in the representatives with good comprehension were significantly improved in the FIL group.

In spite of an increase in ICU survival rates, end-of-life in these units remains frequent. The implications are major not only for patients but also for relatives, with important consequences for our health-care system. Family burden (i.e. the negative impact of ICU experience) increases when the patient dies in the ICU [11]. Different strategies have been tested, both during the patient's hospitalization and after the patient's death, to improve family experience in the months that follow the patient's death. Among these strategies, endof-life family conferences have been developed. These are formal, structured meetings between intensivists (physicians, nurses, etc.) and family members. During these conferences, family members and ICU caregivers discuss the patient's situation in a quiet room. Ideally, family members are given opportunities to ask questions, express concerns, and confront painful emotions with the help of empathetic professionals. End-of-life conferences were specifically assessed in family members of 126 patients dying in 22 ICUs in France in a randomized controlled study [12], showing that these meetings are associated with a significant decrease in anxiety and depression symptoms 3 months after the patient's death. These results further highlight that quality of communication is at the heart of family members' experience. Strategies to improve family experience are most often developed during the patient's ICU stay. However, a recent multicentre randomized controlled trial [13], the first strategy testing outside the ICU, was designed to test the hypothesis that a condolence letter, compared to no condolence letter, could reduce grief symptoms in families of patients who had died in the ICU. Among the 242 patients, 123 were included in the intervention letter group and 119 in the control group. After 6 months, the results were unexpected: the HADS score was significantly worse in the intervention group than in the control group. The prevalence of depression symptoms and the HADS-depression subscale score were also higher in the intervention group. The use of a systematic condolence letter does not seem useful to reduce symptoms of anxiety and depression in families. Different end-of-life situations coexist in ICUs, including brain death followed by organ donation request. Family 
members are at the centre of the decision process as within a limited time frame the team will first announce brain dead and approach relatives about organ donation. Experience of the organ donation process and grief symptoms in relatives of brain dead patients who discussed organ donation in the ICU was recently assessed in a multicentre longitudinal study in 28 ICUs in France [14]. Relatives of non-donor patients reported less support both from the ICU team and during discussions with the coordination team. They were less satisfied with communication with the ICU team and reported less communication about organ donation with the ICU clinicians than relatives of donor patients. More than half of the relatives of nondonors described the decision as difficult and were dissatisfied with the process. Interestingly, the decision to consent to or to refuse organ donation was not associated with anxiety or depression over the 3 months that followed the patient's death. However, this study highlights the importance of quality communication whatever the family's decision.

The main studies assessing anxiety and depression of families are shown in. Table 17.1. Clinicians should be aware that anxiety and depression symptoms are frequent in relatives of ICU patients, especially during and after end-of-life situations. A family information leaflet at the ICU patient admission [10], an appropriate waiting room, regular nurse-physicians meetings to discuss patient and family needs and to avoid contradictions [8], and end-of-life family conferences [12] could help reduce anxiety and depression symptoms of ICU patients' relatives (. Fig. 17.1). Interestingly, a recent qualitative study showed that participation in bereavement research is often beneficial for family families and can be developed [19].

\subsection{Post-traumatic Stress Disorder}

PTSD is a psychological reaction resulting from a situation in which the physical and/or psychological integrity of the patient and/or his/her relatives has been threatened and/or actually affected (including serious accident, violent death, rape, aggression, illness serious, war, and attack). The coping skills of the subject are overwhelmed. The immediate reaction may have been intense fear, helplessness, or horror. In DSM-5, PTSD belongs to the trauma and stress-related disorder category. Individuals who suffer from PTSD systematically avoid any event or discussion leading to his emotions. Despite these strategies, the event keeps coming back to the person's mind in flashback or nightmare. PTSD can lead to clinical impairment in important areas of functioning. PTSD is not rare for families of ICU patients. In a longitudinal European study of Azoulay et al. [20], the stress-related morbidity among family members 90 days after ICU discharge or death was assessed and showed that posttraumatic stress reaction, defined as an impact of event scale (IES) score greater than 30, was found in one-third of family members 90 days after ICU discharge or death of a relative. Risk factors for post-traumatic stress reaction were information perceived as unsatisfactory and sharing end-of-life decisions, as confirmed in another study of the same FAMIREA group [15]. It was also suggested that empowerment of relatives, involving them in every day patient care, bathing, feeding, and aspiration [20], could help reduce the occurrence of PTSD. of relatives of dying patients in ICU has been specifically evaluated. An American study [21] assessed PTSD in family members of patients who died in 11 Washington State hospitals. Families with psychological symptoms were more likely to report that access to a counsellor $(P<.001)$ and information about spiritual services might have been helpful while the patient was in the ICU $(P=0.024)$. The identification and correction of these factors may help decrease the rate of PTSD symptoms in families of end-of-life patients. Another study of the same group [11] focused on PTSD symptoms among family members of patients who died in the ICU. Family members of older patients had lower scores for PTSD $(P=0.026)$. Family members that were present at the time of death $(P=0.021)$ and family members of patients with early family conferences $(P=0.012)$ reported higher symptoms of PTSD. When 
withdrawal of a ventilator was decided, family members reported lower symptoms of depression $(P=0.033)$. In order to assess, in a reproducible and standardized manner, the experience of relatives of patients who die in the ICU, the CAESAR study [22] aimed to develop a specifically designed instrument. The CAESAR score was computed and was strongly associated with post-ICU PTSD in the relatives. This score could be used to identify families at risk and as a primary endpoint in clinical studies. In particular, as also underlined in the study by Kross et al. [11], the finding that family members present at time of death have higher symptoms of PTSD suggests that it may be important to counsel family members accordingly and to allow each individual to make the choice that is best for him or her.

Other strategies have been developed to increase both the patient's and the relatives' well-being, such as an ICU diary [16]. The ICU diary is written for ICU patients during their time of sedation and ventilation. It is written by relatives, nurses, and others. Once conscious, the patient can read the diary in order to better understand what happened in the ICU. Although the ICU diary was initially developed for the patient, this study shows that it also affects family members' well-being and decreases symptoms of PTSD 12 months after the experience.

As found for anxiety and depression symptoms, end-of-life family conferences may also help to reduce PTSD symptoms [12]. In a study mentioned above [12], customized endof-life family conferences, including provision of a brochure on bereavement, resulted in longer meetings in which families felt more supported in making difficult decisions, had more opportunities to speak and to express emotions, were more likely to accept realistic goals of care, and experienced more relief from guilt. These combined effects allowed the decrease incidence of PTSD. In the particular setting of cardiopulmonary resuscitation (CPR) performed outside the hospital, with subsequent admission to the ICU, a multicentre randomized trial [17] showed that giving family members of patients undergoing CPR the option of witnessing the resuscitation sequence was associated with a significantly lower incidence of PTSD-related symptoms than the standard practice regarding family presence. It is worth noting that whether or not the family members were offered the choice, more favourable results of psychological testing were noted when family members were present. This study highlights that relatives can sometimes be considered as active partners rather than passive observers.

Communication with the family of critically ill patients is often insufficient [23], and poor communication is associated with family distress [12]. In light of these findings, an American research team [18] has developed the concept of an ICU communication facilitator, i.e. a social worker or a nurse trained to improve communication between the family and the ICU team. Their interventional study aimed to improve discussions about goals of care and palliative care in the ICU by improving communication between the families and the ICU team. However, there were no significant differences in psychological symptoms at 3 months or anxiety or PTSD at 6 months. The intervention was associated with decreased depressive symptoms at 6 months. The main studies assessing PTSD symptoms in family members are shown in. Table 17.2. Relatives of patients hospitalized in ICU are at high risk of PTSD symptoms. PTSD occurrence significantly alters family, social, and professional life on a daily basis. To reduce this risk, it is important to improve the quality of communication with the patient and his family: using an ICU diary to make sense of the stay in intensive care, psychological support, and improvement of end-life-care and communication. Raising clinicians' awareness to this risk makes it possible to identify high-risk individuals and develop appropriate care for patients and/or their relatives during the ICU stay (. Fig. 17.1) and in the months following the ICU stay. 
- Table 17.2 Main studies assessing post-traumatic stress disorder and cognitive dysfunction

\begin{tabular}{|c|c|c|c|}
\hline Study & Type of study & $\begin{array}{l}\text { Number } \\
\text { of family } \\
\text { members }\end{array}$ & Main results \\
\hline \multirow{2}{*}{$\begin{array}{l}\text { Azoulay } \\
\text { et al. } \\
\text { AURCCM } \\
2005[20]\end{array}$} & \multirow{2}{*}{$\begin{array}{l}\text { Prospective } \\
\text { multicenter } \\
\text { study in } 21 \mathrm{lCUs}\end{array}$} & \multirow[t]{2}{*}{284} & $\begin{array}{l}\text { Post-traumatic stress symptoms were found in } \\
94(33.1 \%) \text { family members. }\end{array}$ \\
\hline & & & $\begin{array}{l}\text { Higher rates were noted among family } \\
\text { members who felt information was incomplete } \\
\text { in the ICU }(48.4 \%) \text {, who shared in decision- } \\
\text { making }(47.8 \%) \text {, whose relative died in the ICU } \\
(50 \%) \text {, whose relative died after end-of-life } \\
\text { decisions }(60 \%) \text {, and who shared in end-of-life } \\
\text { decisions }(81.8 \%) \text {. }\end{array}$ \\
\hline $\begin{array}{l}\text { Lautrette } \\
\text { et al. } \\
\text { NEJM } 2007 \\
{[12]}\end{array}$ & $\begin{array}{l}\text { Prospective } \\
\text { multicenter } \\
\text { study in } 22 \mathrm{lCUs}\end{array}$ & 126 & $\begin{array}{l}\text { The participants in the intervention group } \\
\text { (end-of-life family conference) had a signifi- } \\
\text { cantly lower median IES score than the } 52 \\
\text { participants in the control group ( } 27 \text { vs. } 39 \text {, } \\
P=0.02 \text { ) and a lower prevalence of PTSD- } \\
\text { related symptoms ( } 45 \% \text { vs. } 69 \%, P=0.01 \text { ). }\end{array}$ \\
\hline $\begin{array}{l}\text { Siegel et al. } \\
\text { CCM } 2008 \\
{[24]}\end{array}$ & $\begin{array}{l}\text { Prospective } \\
\text { monocenter } \\
\text { study }\end{array}$ & 41 & $\begin{array}{l}\text { In a cohort of bereaved next of kin of patients } \\
\text { who died in the ICU, } 34 \% \text { met criteria for at } \\
\text { least one psychiatric illness: major depressive } \\
\text { disorder ( } 27 \%) \text {, generalized anxiety disorder } \\
(10 \%) \text {, panic disorder ( } 10 \%) \text {, or complicated } \\
\text { grief disorder ( } 5 \%) \text {. Disorders were more } \\
\text { common in spouses than other kinship } \\
\text { relations, those experiencing additional } \\
\text { stressors after the loss, those who said the } \\
\text { patient was ill <5 years, and those who said the } \\
\text { patient's physician was not comforting. }\end{array}$ \\
\hline
\end{tabular}

- Table 17.2 (continued)

\begin{tabular}{|c|c|c|c|}
\hline Study & Type of study & $\begin{array}{l}\text { Number } \\
\text { of family } \\
\text { members }\end{array}$ & Main results \\
\hline $\begin{array}{l}\text { Gries et al. } \\
\text { Chest } 2010 \\
{[21]}\end{array}$ & $\begin{array}{l}\text { Substudy of a } \\
\text { randomized } \\
\text { multicenter trial } \\
\text { in } 15 \text { ICUs }\end{array}$ & 226 & $\begin{array}{l}\text { Prevalence of PTSD and depressive symptoms } \\
\text { were } 14.0 \% \text { and } 18.4 \% \text {, respectively. Family } \\
\text { characteristics associated with increased } \\
\text { symptoms included female gender (PTSD; depres- } \\
\text { sion), knowing the patient for a shorter duration } \\
\text { (PTSD, depression), and discordance between } \\
\text { family members' preferences for decision-making } \\
\text { and their actual decision-making roles (PTSD; } \\
\text { depression). Depressive symptoms were also } \\
\text { associated with lower educational level. }\end{array}$ \\
\hline $\begin{array}{l}\text { Kross et al. } \\
\text { Chest } 2011 \\
\text { [11] }\end{array}$ & $\begin{array}{l}\text { Substudy of a } \\
\text { randomized } \\
\text { multicenter trial } \\
\text { in } 15 \text { ICUs }\end{array}$ & 226 & $\begin{array}{l}\text { Family members of older patients had lower } \\
\text { scores for PTSD. Family members that were } \\
\text { present at the time of death and family } \\
\text { members of patients with early family } \\
\text { conferences reported higher symptoms of } \\
\text { PTSD. When withdrawal of a ventilator was } \\
\text { ordered, family members reported lower } \\
\text { symptoms of depression. }\end{array}$ \\
\hline $\begin{array}{l}\text { Garrouste } \\
\text { et al. } \\
\text { CCM } 2012 \\
{[16]}\end{array}$ & $\begin{array}{l}\text { Prospective } \\
\text { single-center } \\
\text { study }\end{array}$ & 143 & $\begin{array}{l}\text { An ICU diary significantly affected posttrau- } \\
\text { matic stress-related symptoms in relatives and } \\
\text { surviving patients } 12 \text { months after ICU } \\
\text { discharge. }\end{array}$ \\
\hline
\end{tabular}




\begin{tabular}{|c|c|c|c|}
\hline - Table 17.2 & (continued) & & \\
\hline Study & Type of study & $\begin{array}{l}\text { Number } \\
\text { of family } \\
\text { members }\end{array}$ & Main results \\
\hline $\begin{array}{l}\text { Jabre et al. } \\
\text { NEJM } 2013 \\
{[17]}\end{array}$ & $\begin{array}{l}\text { Randomized } \\
\text { multicenter } \\
\text { study in } 15 \\
\text { prehospital } \\
\text { emergency medi- } \\
\text { cal service units }\end{array}$ & 570 & $\begin{array}{l}\text { In the intervention group, } 211 \text { of } 266 \text { relatives } \\
\text { ( } 79 \% \text { ) witnessed CPR, as compared with } 131 \text { of } \\
304 \text { relatives ( } 43 \% \text { ) in the control group. The } \\
\text { frequency of PTSD-related symptoms was } \\
\text { significantly higher in the control group than } \\
\text { in the intervention group and among family } \\
\text { members who did not witness CPR than } \\
\text { among those who did. }\end{array}$ \\
\hline $\begin{array}{l}\text { Curtis et al. } \\
\text { AJRCCM } \\
2016[18]\end{array}$ & $\begin{array}{l}\text { Randomized } \\
\text { bicenter trial in } \\
\text { two hospitals }\end{array}$ & 268 & $\begin{array}{l}\text { An ICU communication facilitator was not } \\
\text { associated with significant differences in } \\
\text { psychological symptoms at } 3 \text { months or } \\
\text { anxiety or PTSD at } 6 \text { months. }\end{array}$ \\
\hline $\begin{array}{l}\text { Kentish- } \\
\text { Barnes et al. } \\
\text { ICM } 2016 \\
{[22]}\end{array}$ & $\begin{array}{l}\text { Prospective } \\
\text { multicenter } \\
\text { study in } 41 \text { ICUs } \\
\text { in France }\end{array}$ & 600 & $\begin{array}{l}\text { The CAESAR score } 21 \text { days after death in the ICU } \\
\text { is strongly associated with post-ICU burden in } \\
\text { the bereaved relatives. The CAESAR score } \\
\text { should prove a useful primary endpoint in trials } \\
\text { of interventions to improve relatives' well-being. }\end{array}$ \\
\hline $\begin{array}{l}\text { Kentish- } \\
\text { Barnes et al. } \\
\text { ICM } 2017 \\
{[13]}\end{array}$ & $\begin{array}{l}\text { Multicenter } \\
\text { randomized trial } \\
\text { in } 22 \text { ICUs in } \\
\text { France }\end{array}$ & 242 & $\begin{array}{l}\text { In relatives of patients who died in the ICU, a } \\
\text { condolence letter failed to alleviate grief } \\
\text { symptoms and may have worsened PTSD- } \\
\text { related symptoms. }\end{array}$ \\
\hline
\end{tabular}

\section{ICU intensive care unit, CPR cardiopulmonary resuscitation, PTSD post-traumatic stress disorder}

\subsection{Cognitive Dysfunction}

Though data on long-term outcomes in families is limited, it appears that up to $40 \%$ of family members suffer from at least one psychiatric illness 1 year after the patient's ICU stay. Siegel and coworkers [24] performed a small study on the incidence of psychiatric illness in 41 relatives who were primary surrogate decision-makers before the death of a relative in a medical ICU. Among the 41 relatives, 34\% presented criteria for at least one psychiatric illness: major depressive disorder (27\%), generalized anxiety disorder (10\%), panic disorder $(10 \%)$, or complicated grief disorder $(5 \%)$. These disorders were more frequent in spouses (63\% vs. $16 \%$ of other relatives) and in relatives reporting that the physician had not been comforting ( $71 \%$ vs. $23 \%$ ).

While family members are initially relieved that their loved one is "out of the woods" and leaving the ICU, a new world is just beginning, and adjustments can be difficult to navigate, let alone recognize. The person who was in the ICU is no longer "just" the spouse, parent, or child, he or she often becomes a person with multiple needs and, in some way, remains a patient. Three months after their ICU stay, $40 \%$ of patients have global cognition scores of 1.5 SD, which is below the population means [25]. The relative thus becomes a caregiver and is trusted into a role that he or she is not necessarily equipped to deal with, especially without the support and all-encompassing care of the ICU staff. After discharge from the ICU, caregivers frequently realize just how exhausted they are: physically and emotionally, and perhaps there is a financial toll, as well. The focus is intently on the patient, as is necessary, while the needs of the caregiver are often ignored [26]. This can lead to a set 
of psychological symptoms that family members frequently experience but do not have a means to express, as anxiety, depression, PTSD, or cognitive dysfunction. Little is known about the real incidence of cognitive dysfunction in families of ICU patients, in particular in the long run after the patient's ICU discharge or death.

\subsection{Time Points for Family Management}

International guidelines for family-centred care in the ICU have recently been developed [6]. The time points which are crucial for family management are threefold [27]. First, in the $48 \mathrm{~h}$ following ICU admission, comprehension, satisfaction, and symptoms of anxiety and depression should be assessed to answer the family's specific needs, to improve the likelihood that timely and adequate information is provided, and to screen for symptoms of anxiety and/or depression, which might affect participation in the decision-making process. Second, at day 3 , a routine formal family meeting should be held, using a communication strategy that best fits the family's needs. Specific information requested by families must be provided, comprehension should be evaluated by reviewing the medical facts, a care plan should be scheduled, and the family's hopes should be discovered and discussed. Third, in case of shift from curative care to comfort care, a formal end-of life family conference helps reduce family burden and may decrease the risk of subsequent complicated grief. In light of recent interventional studies [13, 28, 29], new communication strategies for patients discharged alive from the ICU and for their relatives should be developed and evaluated.

\section{Conclusion}

Anxiety, depression, and PTSD symptoms are frequent in relatives of ICU patients. In order to decrease family burden, several strategies can be implemented by the ICU team (. Fig. 17.1), including empowerment of family members (. Fig. 17.2). A family information leaflet, an appropriate waiting room, and the use of an ICU diary and of an ICU communication facilitator should be implemented by the ICU team. The information given should be complete, avoiding contradictions. In end-of-life situations, the family may choose to share or not the decision and to be present or not, the comfort of patient continuously ensured, and the end-of-life conferences performed. Family members can also be proactive by asking questions, reading the information leaflet, writing in the ICU diary, being involved in every day patient care (feeding, bathing, aspiration), and staying in contact with the family doctor.

\section{Take Home Messages}

The information given should be complete, avoiding contradictions

Anxiety, depression, and post-traumatic stress disorder (PTSD) symptoms are frequent in relatives of ICU patients

In order to decrease these symptoms, some fundamental steps should be followed, including regular nurse-physician meetings to discuss patient and family needs, having a dedicated information room, having a waiting room, and ensuring that there are no contradictions in the information given to families

End-of-life family conferences should be developed. These are formal, structured meetings between intensivists (physicians, nurses, etc.) and family members during which the patient's situation is discussed in a quiet room. Ideally, family members are given opportunities to ask questions, express concerns, and confront painful emotions with the help of empathetic professionals

As found for anxiety and depression symptoms, end-of-life family conferences may also help to reduce PTSD symptoms 
New communication strategies for patients discharged alive from the ICU and for their relatives should be developed and evaluated

Physicians, nurses, and family doctors have to stay in contact with family members

\section{Funding and Conflict of Interest}

Support was provided solely from institutional and/or departmental sources.

All authors declare the absence of any involvement in any organization with a direct financial interest in the subject of the manuscript.

\section{References}

1. Azoulay E, Pochard F, Chevret S, Lemaire F, Mokhtari M, Le Gall JR, et al. Meeting the needs of intensive care unit patient families: a multicenter study. Am J Respir Crit Care Med. 2001;163(1):135-9.

2. Curtis JR, Patrick DL, Shannon SE, Treece PD, Engelberg RA, Rubenfeld GD. The family conference as a focus to improve communication about end-of-life care in the intensive care unit: opportunities for improvement. Crit Care Med. 2001;29(2 Suppl):N26-33.

3. Heyland DK, Rocker GM, Dodek PM, Kutsogiannis DJ, Konopad E, Cook DJ, et al. Family satisfaction with care in the intensive care unit: results of a multiple center study. Crit Care Med. 2002;30(7):1413-8.

4. Azoulay E, Sprung CL. Family-physician interactions in the intensive care unit. Crit Care Med. 2004;32(11):2323-8.

5. Davidson JE, Jones C, Bienvenu OJ. Family response to critical illness: postintensive care syndrome-family. Crit Care Med. 2012;40(2):618-24.

6. Davidson JE, Aslakson RA, Long AC, Puntillo KA, Kross EK, Hart J, et al. Guidelines for family-centered care in the neonatal, pediatric, and adult ICU. Crit Care Med. 2017;45(1):103-28.

7. Zigmond AS, Snaith RP. The hospital anxiety and depression scale. Acta Psychiatr Scand. 1983;67(6):361-70.

8. Pochard F, Azoulay E, Chevret S, Lemaire F, Hubert P, Canoui P, et al. Symptoms of anxiety and depression in family members of intensive care unit patients: ethical hypothesis regarding decision-makingcapacity. Crit Care Med. 2001;29(10):1893-7.

9. Azoulay E, Chevret S, Leleu G, Pochard F, Barboteu M, Adrie C, et al. Half the families of intensive careunit patients experience inadequate communication with physicians. Crit Care Med. 2000;28(8): 3044-9.

10. Azoulay E, Pochard F, Chevret S, Jourdain M, Bornstain C, Wernet A, et al. Impact of a family information leaflet on effectiveness of information provided to family members of intensive care unit patients:a multicenter, prospective, randomized, controlled trial. Am J Respir Crit Care Med. 2002;165(4): 438-42.

11. Kross EK, Engelberg RA, Gries CJ, Nielsen EL, Zatzick D, Curtis JR. ICU care associated with symptom sof depression and posttraumatic stress disorder among family members of patients who die in the ICU. Chest. 2011;139(4):795-801.

12. Lautrette A, Darmon M, Megarbane B, Joly LM, Chevret S, Adrie C, et al. A communication strategy and brochure for relatives of patients dying in the ICU. N Engl J Med. 2007;356(5):469-78.

13. Kentish-Barnes N, Chevret S, Champigneulle B, Thirion M, Souppart V, Gilbert M, et al. Effect of a condolence letter on grief symptoms among relatives of patients who died in the ICU: a randomized clinical trial. Intensive Care Med. 2017;43(4):473-84. 
14. Kentish-Barnes N, Chevret S, Cheisson G, Joseph L, Martin-Lefevre L, Si Larbi AG, et al. Grief symptom in relatives who experienced organ donation request in the ICU. Am J Respir Crit Care Med. 2018;198(6):751-8.

15. Azoulay E, Pochard F, Chevret S, Adrie C, Annane D, Bleichner G, et al. Half the family members of intensive care unit patients do not want to share in the decision-making process: a study in 78 French intensive care units. Crit Care Med. 2004;32(9):1832-8.

16. Garrouste-Orgeas M, Coquet I, Perier A, Timsit JF, Pochard F, Lancrin F, et al. Impact of an intensive care unit diary on psychological distress in patients and relatives*. Crit Care Med. 2012;40(7): 2033-40.

17. Jabre P, Belpomme V, Azoulay E, Jacob L, Bertrand L, Lapostolle F, et al. Family presence during cardiopulmonary resuscitation. N Engl J Med. 2013;368(11):1008-18.

18. Curtis JR, Treece PD, Nielsen EL, Gold J, Ciechanowski PS, Shannon SE, et al. Randomized trial of communication facilitators to reduce family distress and intensity of endof-life care. Am J Respir Crit Care Med. 2016;193(2):154-62.

19. Kentish-Barnes N, McAdam JL, Kouki S, Cohen-Solal Z, Chaize M, Galon M, et al. Research participation for bereaved family members: experience and insights from a qualitative study. Crit Care Med. 2015;43(9):1839-45.

20. Azoulay E, Pochard F, Kentish-Barnes N, Chevret S, Aboab J, Adrie C, et al. Risk of post-traumatic stress symptoms in family members of intensive care unit patients. Am $\mathbf{J}$ Respir Crit Care Med. 2005;171(9):987-94.

21. Gries CJ, Engelberg RA, Kross EK, Zatzick D, Nielsen EL, Downey L, et al. Predictors of symptoms of posttraumatic stress and depression in family members after patient death in the ICU. Chest. 2010;137(2):280-7.

22. Kentish-Barnes N, Seegers V, Legriel S, Cariou A, Jaber S, Lefrant JY, et al. CAESAR: a new tool to assess relatives' experience of dying and death in the ICU. Intensive Care Med. 2016;42(6):995-1002.

23. Fassier T, Darmon M, Laplace C, Chevret S, Schlemmer B, Pochard F, et al. One-day quantitative cross-sectional study of family information time in 90 intensive care units in France. Crit Care Med. 2007;35(1):177-83.

24. Siegel MD, Hayes E, Vanderwerker LC, Loseth DB, Prigerson HG. Psychiatric illness in the next of kin of patients who die in the intensive care unit. Crit Care Med. 2008;36(6):17228 .

25. Pandharipande PP, Girard TD, Jackson JC, Morandi A, Thompson JL, Pun BT, et al. Long-term cognitive impairment after critical illness. N Engl J Med. 2013;369(14):1306-16. 26. Schmidt M, Azoulay E. Having a loved one in the ICU: the forgotten family. Curr Opin Crit Care. 2012;18(5):540-7.

27. Kentish-Barnes N, Lemiale V, Chaize M, Pochard F, Azoulay E. Assessing burden in families of critical care patients. Crit Care Med. 2009;37(10 Suppl):S448-56.

28. Curtis JR, Back AL, Ford DW, Downey L, Shannon SE, Doorenbos AZ, et al. Effect of communication skills training for residents and nurse practitioners on quality of communication with patients with serious illness: a randomized trial. JAMA. 2013;310(21):2271-81.

29. Carson SS, Cox CE, Wallenstein S, Hanson LC, Danis M, Tulsky JA, et al. Effect of palliative care-led meetings for families of patients with chronic critical illness: a randomized clinical trial. JAMA. 2016;316(1):51-62. 